PART II. PHYSICAL ACTIVITY OF SOCIAL AND PROFESSIONAL GROUPS DZIAŁ II. AKTYWNOŚĆ FIZYCZNA GRUP SPOŁECZNYCH I ZAWODOWYCH

\title{
IS THERE A NEED FOR A WEIGHT MANAGEMENT CONTROL PROGRAM IN HEMODIALYSIS PATIENTS? THE IMPLICATION OF EXERCISE PROGRAMS
}

\section{CZY JEST POTRZEBA STOSOWANIA PROGRAMU KONTROLI WAGI U PACJENTÓW PODDAWANYCH HEMODIALIZIE? WYKORZYSTANIE PROGRAMÓW ĆWICZEŃ}

\author{
Špela Bogataj ${ }^{1,2(B, C, E, F)}$, Jernej Pajek ${ }^{1,3(A, E)}, J^{2}$ adranka Buturović Ponikvar ${ }^{1,3(A, E)}$, Maja Pajek $^{2(A, E)}$
}

\author{
${ }^{1}$ Department of Nephrology, University Medical Centre, Ljubljana, Slovenia \\ ${ }^{2}$ Faculty of Sport, University of Ljubljana, Slovenia \\ ${ }^{3}$ Faculty of Medicine, University of Ljubljana, Slovenia
}

Authors' contribution Wkład autorów:

A. Study design/planning zaplanowanie badań B. Data collection/entry zebranie danych

C. Data analysis/statistics dane - analiza i statystyki D. Data interpretation interpretacja danych E. Preparation of manuscript przygotowanie artykułu F. Literature analysis/search wyszukiwanie i analiza literatury G. Funds collection zebranie funduszy

\section{Summary}

Background. In hemodialysis (HD) patients, age-related muscle loss and body composition changes are more intense than in those with normal renal function. This study aimed to determine the effects of functional training in addition to intradialytic cycling exercise, compared to intradialytic cycling alone on body composition in HD patients.

Material and methods. Patients were randomized to an experimental group ( $n=20$; functional training and intradialytic cycling) or control group ( $\mathrm{n}=20$; intradialytic cycling) over 16 weeks. In the first 8 weeks, the experimental group attended guided functional training before dialysis, and afterward performed functional training at home.

Results. After 16 weeks, a significant intergroup difference was found only in total body water only $(p=0.037)$ in favor of the experimental group. Significant intragroup changes were found for weight (after 8 weeks: $p=0.009$; after 16 weeks: $p=0.012$ ), waist circumference (after 8 weeks: $\mathrm{p}=0.026$; after 16 weeks: $\mathrm{p}=0.044$ ), and BMI (after 16 weeks: $\mathrm{p}=0.046$ ) in the experimental group and for fat tissue index (after 16 weeks: $p=0.038$ ) in the control group. Overall exercise compliance was high, reaching more than two-thirds of prescribed exercise volumes.

Conclusions. Our results showed increased weight and BMI following functional training in HD patients. This increase was not a result of an increase in body fat, which was illustrated by unchanged results in fat tissue index.

Keywords: hemodialysis, body composition, functional training, intradialytic cycling, impact

\section{Streszczenie}

Wprowadzenie. U pacjentów poddawanych hemodializie związane z wiekiem utrata mięśni i zmiany w składzie ciała są bardziej intensywne niż u osób z prawidłowym funkcjonowaniem nerek. Celem badania było określenie wpływu treningu funkcjonalnego jako dodatku do śróddializacyjnych ćwiczeń na rowerze $\mathrm{w}$ porównaniu z samymi śróddializacyjnymi ćwiczeniami na rowerze na skład ciała pacjentów poddawanych hemodializie.

Materiał i metody. Pacjenci zostali losowo przypisani do grupy doświadczalnej (n=20, trening funkcjonalny i śróddializacyjna jazda na rowerze) albo kontrolnej ( $n=20$, śróddializacyjna jazda na rowerze) na 16 tygodni. Przez pierwszych osiem tygodni grupa doświadczalna uczestniczyła w prowadzonych przez trenera treningach funkcjonalnych przed poddaniem się dializie i wykonywała trening funkcjonalny w domu.

Wyniki. Po 16 tygodniach pomiędzy grupami zaszła istotna zmiana w zakresie całkowitej zawartości wody w ciele $(\mathrm{p}=0,037)$ na korzyść grupy doświadczalnej. Wykazano zasadnicze różnice między grupami w zakresie wagi (po 8 tygodniach: $p=0,009$; po 16 tygodniach: $\mathrm{p}=0,012$ ), obwodu pasa (po 8 tygodniach: $\mathrm{p}=0,026$; po 16 tygodniach $\mathrm{p}=0,044$ ) i wartości BMI (po 16 tygodniach: $p=0,046$ ) w grupie doświadczalnej oraz w zakresie wskaźnika tkanki tłuszczowej (po 16 tygodniach: $\mathrm{p}=0,038$ ) w grupie kontrolnej. Ogólna zgodność ćwiczeń była wysoka i sięgała ponad 2/3 przepisanych ćwiczeń.

Wnioski. Wyniki wykazały zwiększoną wagę i BMI w następstwie treningu funkcjonalnego u pacjentów poddawanych dializoterapii. Wzrost ten nie był efektem zwiększenia zawartości tłuszczu w ciele, co potwierdził brak zmian we wskaźniku tkanki tłuszczowej.

Słowa kluczowe: hemodializa, skład ciała, trening funkcjonalny, ćwiczenia śróddializacyjne na rowerze, wpływ References: 30 Submitted: 2020 Aug 3 Accepted: 2020 Oct 19

Bogataj S, Pajek J, Buturović Ponikvar J, Pajek M. Is there a need for a weight management control program in hemodialysis patients? The implication of exercise programs. Health Prob Civil. 2021; 15(1): 29-36. https://doi.org/10.5114/hpc.2020.100396

Address for correspondence / Adres korespondencyjny: Maja Pajek, Faculty of Sport, University of Ljubljana, Gortanova ul. 22, 1000 Ljubljana, Slovenia, e-mail: maja.pajek@fsp.uni-lj.si, phone: +38615207 700

ORCID: Spela Bogataj https://orcid.org/0000-0003-1784-208X, Jernej Pajek https://orcid.org/0000-0003-3265-8053,

Jadranka Buturović Ponikvar https://orcid.org/0000-0001-7473-3731, Maja Pajek https://orcid.org/0000-0002-2706-7729

Copyright: (C) Pope John Paul II State School of Higher Education in Biała Podlaska, Špela Bogataj, Jernej Pajek, Jadranka Buturović Ponikvar, Maja Pajek. This is an Open Access journal, all articles are distributed under the terms of the Creative Commons Attribution-NonCommercial-ShareAlike 4.0 International (CC BY-NC-SA 4.0) License (http://creativecommons.org/licenses/by-nc-sa/4.0/), allowing third parties to copy and redistribute the material in any medium or format and to remix, transform, and build upon the material, provided the original work is properly cited and states its license. 


\section{Introduction}

Chronic kidney disease (CKD) is an increasing public health issue, with an estimated prevalence of $8 \%-16 \%$ worldwide [1]. Although options, such as hemodialysis (HD), reduce mortality and morbidity, end-stage kidney disease patients still experience meaningfully poor physical fitness, psychosocial problems, and lower quality of life [2]. Body fat measurement in HD patients is essential, as even minor changes in total body fat may have a significant impact on patient survival [3]. Increased body fat has been positively correlated with increased proinflammatory cytokines in dialysis patients [4].

Ruiz et al. found a high prevalence of obesity in HD patients and recommended physical exercise [5]. Intradialytic cycling is the most common intradialytic exercise that was shown to improve exercise capacity [6], physical function, quality of life [6,7], and blood pressure [7] in HD patients. Wilund et al. [8] found that intradialytic endurance exercise training reduced the thickness of the epicardial fat layer by $11 \%$. However, according to Mobbs \& Makimura [9], there is undistinguishable advice for obese individuals to lose fat in medical practice. Moreover, a defined practice that dialysis patients should aggressively lose weight as a prerequisite to be listed and to remain on kidney transplant waiting lists is questionable [10]. On the contrary, Carrero et al. [11] showed that large body size and higher fat mass are linked with better survival in dialysis patients. Therefore, clinical trials to increase weight, muscle mass, and even body fat in dialysis patients may be needed instead of decreasing the mentioned body composition parameters [3].

Functional training is designed to simulate the activities of daily living [12]. It is composed of lower body and upper body movements with multi-joint activities [13]. Functional training in older adults demonstrated positive effects on muscle strength, daily living activities, and physical functioning [14]. It was stated that this training type, which imitates daily tasks, yields the most significant performance gains.

A most recent meta-analysis showed the largest effect sizes for combined types of exercise compared to solely aerobic or resistance training types [15]. Therefore, due to paradoxical findings that have led to confusion with regard to weight management in HD patients, we have conducted a study to determine the effects of functional training added to intradialytic exercise on body composition in HD patients, and compared that to intradialytic exercise alone. Additionally, we examined the effects of an unsupervised, home-based functional exercise program on body composition in the functional training group.

\section{Material and methods}

The present study is a sub-analysis of a randomized, interventional, controlled trial comparing two types of exercise training prescription and counseling in HD patients [16]. Eighty-two HD patients were approached in the HD units of the University Medical Centre, Ljubljana, Slovenia. Forty patients were randomly assigned to either a kinesiologist-guided functional training coupled with intradialytic cycling (n=20, age: $65.2 \pm 12.1$ years), or intradialy tic cycling only ( $n=20$, age: $61.9 \pm 13.0$ years). Group allocation was performed by a computer program (Random Allocation Software). Thirty-four patients were analyzed at the end of the study. The flow of the subjects is presented in Figure 1.

The inclusion criteria were the following: end-stage kidney disease, renal replacement therapy with HD>3 months, age 18-90 years, capable of independent walking and feeding, in a stable medical condition. Exclusion criteria were: chronic malignant or infectious disease, uncontrolled arterial hypertension with an average of the last five in-center pre-dialysis blood pressure values above 180/100 mm Hg, angina pectoris of Canadian Cardiovascular Society grade 2-4, New York Heart Association heart failure grade 3 or 4, the presence of psychotic illness or mental disability, a history of limb amputation (more than two toes and/or more than two fingers) or any other condition that might cause clinical instability of the patient (e.g., repetitive gastrointestinal hemorrhages, liver cirrhosis with frequent exacerbations, advanced dementia with poor cooperation of the patient). Study withdrawal criteria included any intercurrent illness or trauma that prevented the patient from continuing with the exercise program for a period longer than 14 days, the occurrence of an acute illness lasting more than 3 weeks or ending less than 3 weeks before the end of the study, or if the patient has had prescribed medication for it at the end of the study, diagnosis of malignant disease during the course of the research, and withdrawal of the consent to participate. Approval from the National Medical Ethics Committee (Ministry of Health, Republic of Slovenia, document number 0120-97/2017-3 KME 68/03/17) and written informed consent were attained in all cases. The study complies with the Declaration of Helsinki. Registration of the study can be found at ClinicalTrials.Gov (Clinicaltrials.gov identifier: NCT03334123). 


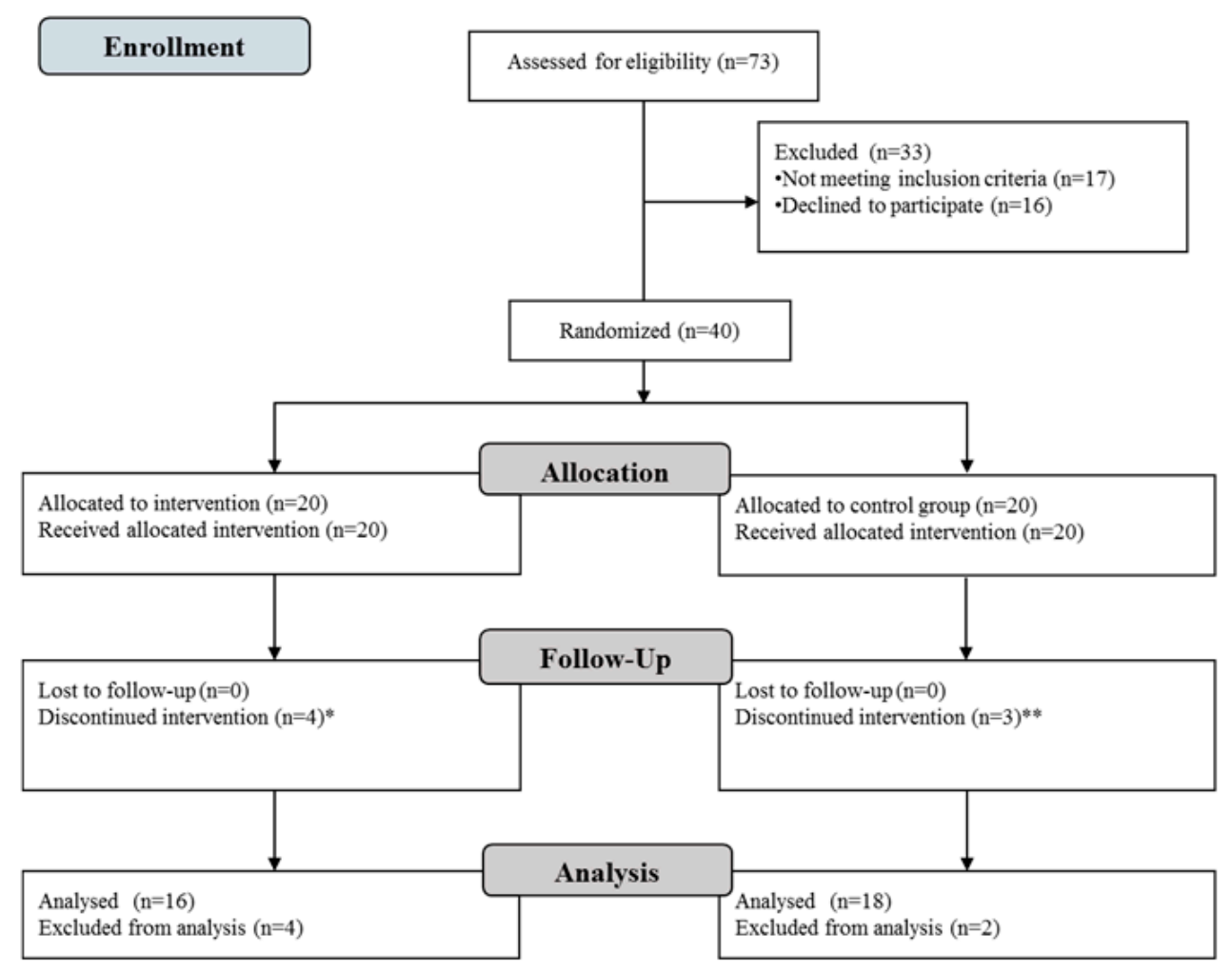

Figure 1. CONSORT (Consolidated Standards of Reporting Trials) diagram

Notes: *death ( $\mathrm{n}=1)$, sepsis $(\mathrm{n}=1)$, fall and osteomuscular injury $(\mathrm{n}=1)$, discontinued on patient's demand; exacerbated symptoms of spinal stenosis $(\mathrm{n}=1)$, **discontinued on patient's demand $(\mathrm{n}=1)$, coronary artery disease exacerbation with exertional dyspnea $(\mathrm{n}=1)$, transplantation $(\mathrm{n}=1)$.

\section{Procedures}

Height, weight, waist circumference, and body composition were measured using bioimpedance analysis (Body Composition Monitor, Fresenius AG, Bad Homburg, Germany). The bioimpedance analysis has been validated in HD population [17]. Dual-energy X-ray absorptiometry (DEXA) is considered the "gold standard" for assessing body composition [4,17]; however, measurements with DEXA are too expensive [18], and only a few dialysis clinics have direct access to them. Bioelectrical impedance analysis (BIA) is a non-invasive and inexpensive method that does not require highly trained personnel, and studies have shown good reproducibility in HD patients $[19,20]$. BIA was performed while the patient was lying on the bed, with electrodes placed on their wrist and foot. Outcomes were assessed 3 times on nondialysis days: before the start of the intervention, after 8 weeks (phase 1), and after 16 weeks (phase 2). The body composition variables measured were BIA assessed overhydration, total body water, body mass index (BMI), fat tissue index (FTI), lean tissue index (LTI), and phase angle.

The exact study exercise interventions and protocol were described previously [16]. In short, 40 voluntary HD patients were recruited at hemodialysis units of the University Medical Centre in Ljubljana, Slovenia, to participate in a prospective randomized controlled trial comparing the effects of 2 exercise programs. Randomization was done with a computer program (Random Allocation Software) to the experimental (EXP) and to control (CON) group (see Figure 2). The EXP group engaged in guided functional exercise training before each HD session ( 3 days a week) and additional intradialytic cycling exercise (3 days a week). After 8 weeks, predialysis functional training exercise was terminated, and patients were instructed and motivated to perform functional exercise routines at home on nondialysis days for an additional 8 weeks ( 3 days a week). On dialysis days, intradialytic cycling was continued (3 days a week). The control (CON) group performed intradialytic cycling only in both study periods (16 weeks; 3 days a week). Details of interventions are explained in Table 1. 
Table 1. Description of the interventions

\begin{tabular}{|c|c|c|c|c|}
\hline Information & $\begin{array}{c}\text { Guided functional } \\
\text { training }\end{array}$ & Exercise counseling & $\begin{array}{c}\text { Home-based } \\
\text { functional training }\end{array}$ & Intradialytic cycling \\
\hline Frequency & 3 times a week & 3 times a week & 3 times a week & 3 times a week \\
\hline Intensity & $\begin{array}{l}\text { adjustment of } \\
\text { repetitions, sets, } \\
\text { and weight to each } \\
\text { individual } \\
\text { 7-8 rate of perceived } \\
\text { exertion (RPE) on a } 10 \\
\text { grade Borg scale }\end{array}$ & & $\begin{array}{l}\text { adjustment of } \\
\text { repetitions, sets, } \\
\text { and weight to each } \\
\text { individual } \\
\text { 7-8 RPE (Borg scale) }\end{array}$ & $\begin{array}{l}\text { 4-5 RPE (Borg scale) } \\
\text { gradual increase of } \\
\text { cycling resistance }\end{array}$ \\
\hline Type & $\begin{array}{l}\text { full-body exercises } \\
\text { to train balance, } \\
\text { coordination, strength, } \\
\text { flexibility endurance, } \\
\text { and power } \\
\text { Warm up } \\
\text { - light cardiovascular } \\
\text { exercises } \\
\text { - coordination } \\
\text { exercises } \\
\text { - balance exercises } \\
\text { Main part } \\
\text { modifications of: } \\
\text { - squats } \\
\text { - lunges } \\
\text { - push-ups } \\
\text { - pull exercises } \\
\text { - leg raises } \\
\text { - modified side plank, } \\
\text { pallof press, sit-ups, } \\
\text { seated rotations, } \\
\text { glute bridges, bird } \\
\text { dog, medicine ball } \\
\text { chest squeeze } \\
\text { Cooldown } \\
\text { - light stretching } \\
\text { exercises } \\
\end{array}$ & $\begin{array}{l}\text { explanation of which } \\
\text { muscles are engaged in } \\
\text { an exercise } \\
\text { explanation of the } \\
\text { correct technique } \\
\text { motivation, } \\
\text { encouragements } \\
\text { during home-based } \\
\text { training: advice, } \\
\text { feedback, personalized } \\
\text { program } \\
\text { during guided } \\
\text { functional training in } \\
\text { the first eight weeks; } \\
\text { during dialysis in the } \\
\text { second eight weeks }\end{array}$ & $\begin{array}{l}\text { transferring exercises } \\
\text { from the guided part } \\
\text { to home environment } \\
\text { use of home } \\
\text { equipment: towels, } \\
\text { plastic bottles, chair, } \\
\text { table etc. } \\
\text { written personal } \\
\text { exercise program with } \\
\text { illustrations }\end{array}$ & $\begin{array}{l}\text { performed on a } \\
\text { customized ergometer } \\
\text { the same instructions } \\
\text { for EXP and CON group }\end{array}$ \\
\hline Time/duration & approximately $30 \mathrm{~min}$ & approximately $20 \mathrm{~min}$ & approximately $45 \mathrm{~min}$ & $\begin{array}{l}\text { initial duration: } 15 \mathrm{~min} \\
\text { goal duration: } 60 \mathrm{~min}\end{array}$ \\
\hline
\end{tabular}

Notes: EXP - experimental group, CON - control group.

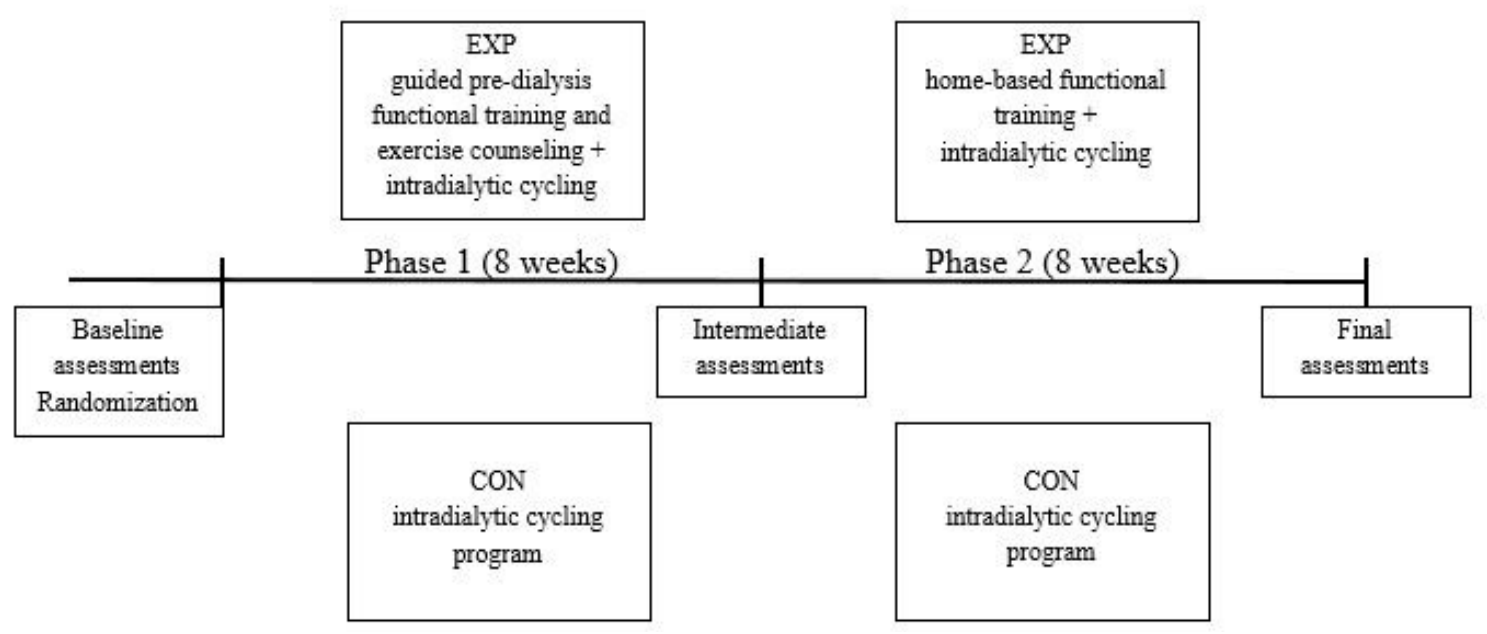

Figure 2. Timeline of the randomized controlled study design 


\section{Statistical analysis}

We tested differences between the EXP and CON groups with the analysis of covariance (ANCOVA), using the baseline value as a covariate. Intragroup changes over time were analyzed with paired t-test. The independent t-test was used to compare the baseline values between the groups. All analyses were made using SPSS, v.22 (SPSS Inc., Chicago, IL, USA), and assessed at the $\mathrm{p}<0.05$ level of significance.

\section{Results}

Patients' demographic and clinical characteristics are presented in Table 2. We studied the outcome of 40 HD patients, with an average age of $63.6 \pm 12.5$. They were treated with conventional HD 3 times a week, with a mean weekly duration of $12.9 \pm 2.3$ hours. There were no statistically significant differences between the groups.

Table 2. Demographic and clinical characteristics

\begin{tabular}{|l|c|c|c|}
\hline \multicolumn{1}{|c|}{ Characteristics } & $\begin{array}{c}\text { All participants } \\
(\mathbf{n = 4 0 )}\end{array}$ & $\begin{array}{c}\text { Experimental group } \\
(\mathbf{n = 2 0})\end{array}$ & $\begin{array}{c}\text { Control group } \\
(\mathbf{n = 2 0})\end{array}$ \\
\hline Age (years) & $63.6 \pm 12.5$ & $65.2 \pm 12.1$ & $61.9 \pm 13.0$ \\
\hline Male sex (\%) & $55 \%$ & $60 \%$ & $50 \%$ \\
\hline Height (cm) & $167.9 \pm 9.8$ & $168.4 \pm 9.6$ & $7.5 \pm 7.3$ \\
\hline Dialysis vintage (years) & $7.4 \pm 7.7$ & $7.4 \pm 8.1$ & $13.3 \pm 1.9$ \\
\hline Weekly dialysis duration (h) & $12.9 \pm 2.3$ & $12.5 \pm 2.7$ & $122 \pm 11.3$ \\
\hline Hemoglobin (g/L) & $120.2 \pm 9.6$ & $118 \pm 7.3$ & $39.6 \pm 2.5$ \\
\hline Albumin (g/L) & $39.5 \pm 2.9$ & $39.4 \pm 3.2$ & $10.1 \pm 20.0$ \\
\hline C-reactive protein (mg/L) & $9.2 \pm 17.2$ & $8.5 \pm 14.2$ & $1.5 \pm 0.5$ \\
\hline Phosphorous (mmol/L) & $1.5 \pm 0.5$ & $1.5 \pm 0.5$ & $144 \pm 13.4$ \\
\hline Systolic blood pressure (mm Hg) & $140 \pm 15.1$ & $138 \pm 16.0$ & $84 \pm 9.38$ \\
\hline Diastolic blood pressure (mm Hg) & $81 \pm 10.1$ & $78 \pm 10.2$ & $751 \pm 143$ \\
\hline Serum creatinine (qmol/L) & $751 \pm 148$ & $750 \pm 156$ & $25.4 \pm 5.73$ \\
\hline Urea (mmol/L) & $24 \pm 5.8$ & $22.6 \pm 5.7$ & \\
\hline
\end{tabular}

Compliance to exercise programs was defined as the total number of completed exercise sessions divided by the total number of sessions offered. In phase 1, compliance of the EXP group for functional training and cycling sessions were $87 \pm 12 \%$ and $90 \pm 12 \%$, respectively. Intradialytic cycling compliance of the CON group was $87 \pm 10 \%$ (phase 1 ). In the $8^{\text {th }}$ week, after a gradual increase in duration, the mean intradialytic cycling routine duration was $30.5 \pm 8.3 \mathrm{~min}$ for the EXP group and $31.8 \pm 7.8 \mathrm{~min}$ for the CON group ( $>0.05)$. In the $16^{\text {th }}$ study week, the EXP group cycled for $46.6 \pm 17.0 \mathrm{~min}$ and control group for $44.4 \pm 12.8 \mathrm{~min}$ ( $\mathrm{p}>0.05$ ). In phase 2 , the experimental group completed $73 \% \pm 21 \%$ of advised at home functional exercise sessions and $82 \% \pm 19 \%$ of incenter cycling sessions. CON group compliance (cycling) in phase 2 was $82 \% \pm 13 \%$. There were no significant differences between the groups in intradialytic cycling compliance during either study phases. However, there was a significantly ( $\mathrm{p}=0.034)$ lower adherence to home-based functional exercise in contrast to in-center predialysis functional exercise in the EXP group.

Table 3 shows the results for each measurement for both groups. There was a significant intergroup difference after 16 weeks in total body water only ( $\mathrm{p}=0.037)$. Significant intragroup changes over time were found for weight (after 8 weeks: $p=0.009$; after 16 weeks: $p=0.012$ ), waist circumference (after 8 weeks: $p=0.026$; after 16 weeks: $p=0.044$ ), and BMI (after 16 weeks: $p=0.046$ ) in the EXP group, and fat tissue index (after 16 weeks: $\mathrm{p}=0.038$ ) in the CON group. All other parameters did not significantly change.

Table 3. Values at baseline, 8 weeks, and 16 weeks with inter and intragroup differences

\begin{tabular}{|l|c|c|c|c|}
\hline \multicolumn{1}{|c|}{ Variable } & Group & Baseline & $\mathbf{8}$ weeks & 16 weeks \\
\hline \multirow{2}{*}{ Weight (kg) } & EXP & $72.6 \pm 16.1$ & $73.8 \pm 14.9^{*}$ & $73.8 \pm 15.3^{*}$ \\
\cline { 2 - 5 } & CON & $71.7 \pm 15.9$ & $71.9 \pm 16.5$ & $71.8 \pm 16.4$ \\
\hline \multirow{2}{*}{ Waist circumference (cm) } & EXP & $98.4 \pm 12.2$ & $96.2 \pm 12.9^{*}$ & $96.1 \pm 13.4^{*}$ \\
\cline { 2 - 5 } & CON & $94.8 \pm 16.8$ & $95.9 \pm 14.1$ & $95.5 \pm 14.2$ \\
\hline \multirow{2}{*}{ BIA assessed overhydration (L) } & EXP & $0.9 \pm 1.2$ & $0.7 \pm 1.2$ & $0.8 \pm 1.1$ \\
\cline { 2 - 5 } & CON & $1.3 \pm 2.4$ & $1.2 \pm 2.2$ & $1.4 \pm 2.3$ \\
\hline
\end{tabular}




\begin{tabular}{|l|c|c|c|c|}
\hline \multirow{2}{*}{ Total body water $(\mathbf{L})$} & EXP & $37.5 \pm 7.6$ & $37.6 \pm 7.3$ & $37.4 \pm 7.4 \#$ \\
\cline { 2 - 4 } & CON & $35.1 \pm 6.4$ & $35.0 \pm 6.1$ & $33.6 \pm 5.6$ \\
\hline \multirow{2}{*}{ Body mass index $\left(\mathbf{k g} / \mathbf{m}^{2}\right)$} & EXP & $25.5 \pm 4.8$ & $25.8 \pm 4.4$ & $26.0 \pm 4.7^{*}$ \\
\hline \multirow{2}{*}{ Lean tissue index $\left(\mathbf{k g} / \mathbf{m}^{2}\right)$} & CON & $25.6 \pm 5.4$ & $25.8 \pm 5.5$ & $25.9 \pm 5.2$ \\
\hline \multirow{2}{*}{ Fat tissue index $\left(\mathbf{k g} / \mathbf{m}^{2}\right)$} & EXP & $13.6 \pm 3.2$ & $14.5 \pm 2.5$ & $14.5 \pm 2.4$ \\
\hline \multirow{2}{*}{ Phase angle $\left({ }^{\circ}\right)$} & CON & $12.9 \pm 2.0$ & $13.3 \pm 2.5$ & $12.4 \pm 1.9$ \\
\cline { 2 - 4 } & EXP & $11.4 \pm 4.8$ & $10.9 \pm 4.1$ & $10.9 \pm 4.4$ \\
\cline { 2 - 4 } & CON & $11.6 \pm 6.4$ & $11.9 \pm 6.3$ & $12.9 \pm 6.1^{*}$ \\
\cline { 2 - 4 } & EXP & $5.2 \pm 0.9$ & $5.4 \pm 0.9$ & $5.3 \pm 0.9$ \\
\hline
\end{tabular}

Notes: EXP - experimental group, CON - control group, BIA - bioimpedance performed using Body Composition Monitor, Fresenius AG, Bad Homburg, Germany. \# p <0.05 indicates significant intergroup difference, ${ }^{*} \mathrm{p}<0.05$ indicates significant intragroup difference compared to the baseline value.

\section{Discussion}

In HD patients, age-related muscle loss and body composition changes are more intense than those with normal renal function [21]. There is a significant increase in fat mass, along with a decrease in muscle mass during the first two years of HD therapy [22]. This study examined changes in body composition in HD patients during functional training added to intradialy tic cycling. Changes were also studied for the control group, which performed intradialytic cycling only. Additionally, we examined the effects of the unsupervised, home-based exercise program in the functional training group.

The main findings in this study paper were that eight weeks of functional training added to intradialytic exercise, performed under the supervision of a qualified kinesiologist, is feasible, well-tolerated, and successful in weight management among HD patients. Furthermore, similar changes were observed following an unsupervised, home-based functional exercise program, with significant differences between the groups only in total body water. Currently, there is confusion concerning obesity management in hemodialysis patients. Hickel [23] stated that patients with chronic kidney disease believe that their BMI alone can prevent them from being a suitable candidate for kidney transplantation. Accordingly, it was found that hemodialysis patients with increased BMI have a better survival rate $[24,25]$. This phenomenon can be explained by the fact that extra fat mass could be protective for HD patients in the short term [26].

Our results showed increased body weight in the functional training group and accordingly increased BMI. However, the increase in weight and BMI could be due to the increase in total body water and lean tissue index and not due to the fat tissue (Table 3). This increase is an important clinical outcome because sarcopenia occurs on a gradual basis during aging progression [27]. Since sarcopenia is strongly related to muscular weakness, dysfunction, and disease comorbidity, the capacity to increase lean tissue through participation in functional exercise represents an effective preventive strategy, and certainly more translational studies are warranted to examine treatment options for the aforementioned consequences directly. Previous trials have reported contradictory results regarding the link between obesity and mortality in the CKD patients. It has been shown that patients with low BMI are at higher risk of mortality than those within the normal BMI range [28,29]. A recent meta-analysis [30] has shown that for every $1 \mathrm{~kg} / \mathrm{m}^{2}$ increase in BMI, there is a reduction in the risk of all-cause and cardiovascular mortality by $3 \%$ and $4 \%$, respectively, in patients undergoing HD.

The limitation of the study was the non-existence of a control group that engaged in routine HD care only. Therefore, it was not possible to unequivocally describe the observed effects of an exercise intervention on body composition because of the lack of an inactive control group. Moreover, we did not measure dietary intake in this study, so we were unable to relate body composition changes directly to changes induced by an exercise program. The small sample size should also be considered as a limitation. However, the novelty of the current study is the fact that this is the first study that examined functional training in HD patients, and its effects on body composition. Additionally, functional training showed to be beneficial for improving lean tissue index in HD patients, which is important for their better quality of life.

\section{Conclusions}

Our results showed increased weight and BMI following functional training in HD patients. However, the increased weight and body composition was not the result of an increase in body fat, as indicated by unchanged results in fat tissue index. This is of great importance, since body composition is typically altered among patients 
undergoing maintenance HD. Moreover, body composition measurement can be considered as a significant predictor of mortality outcomes among HD patients. Therefore, changes in body composition can also be considered as a significant predictor of clinical outcome. Our results showed that exercise training programs seem to be a safe and feasible option for the treatment of weight loss, muscle wasting, and weakness that are commonly seen among HD patients. We can state that body composition assessment can provide prognostic data for HD patients. Further studies on interventions to preserve muscle mass and function that may have positive effects on important clinical outcomes are still needed.

\section{Disclosures and acknowledgements}

The authors declare no conflict of interest.

\section{References:}

1. Jha V, Garcia-Garcia G, Iseki K, Li Z, Naicker S, Plattner B, et al. Chronic kidney disease: global dimension and perspectives. Lancet. 2013; 382(9888): 260-272. https://doi.org/10.1016/S0140-6736(13)60687-X

2. Konstantinidou E, Koukouvou G, Kouidi E, Deligiannis A, Tourkantonis A. Exercise training in patients with end-stage renal disease on hemodialysis: comparison of three rehabilitation programs. J Rehabil Med. 2002; 34(1): 40-45. https://doi.org/10.1080/165019702317242695

3. Kalantar-Zadeh K, Kuwae N, Wu DY, Shantouf RS, Fouque D, Anker SD, et al. Associations of body fat and its changes over time with quality of life and prospective mortality in hemodialysis patients. Am. J. Clin. Nutr. 2006; 83(2): 202-210. https://doi.org/10.1093/ajcn/83.2.202

4. Donadio C, Halim AB, Caprio F, Grassi G, Khedr B, Mazzantini M. Single- and multi-frequency bioelectrical impedance analyses to analyse body composition in maintenance haemodialysis patients: Comparison with dual-energy x-ray absorptiometry. Physiol. Meas. 2008; 29(6). https://doi.org/10.1088/0967-3334/29/6/S43

5. Gallar-Ruiz P, Di-Gioia MC, Lacalle C, Rodríguez-Villareal I, Laso-Arias N, Hinostroza-Yanahuaya J, et al. [Body composition in patients on haemodialysis: relationship between the type of haemodialysis and inflammatory and nutritional parameters]. Nefrologia. 2012; 32(4): 467-476 (in Spanish).

6. Chung YC, Yeh ML, Liu YM. Effects of intradialytic exercise on the physical function, depression and quality of life for haemodialysis patients: a systematic review and meta-analysis of randomised controlled trials. J. Clin. Nurs. 2017; 26(13-14): 1801-1813. https://doi.org/10.1111/jocn.13514

7. Sheng K, Zhang P, Chen L, Cheng J, Wu C, Chen J. Intradialytic exercise in hemodialysis patients: a systematic review and meta-analysis. Am. J. Nephrol. 2014; 40(5): 478-490. https://doi.org/10.1159/000368722

8. Wilund KR, Tomayko EJ, Wu PT, Ryong Chung H, Vallurupalli S, Lakshminarayanan B, et al. Intradialytic exercise training reduces oxidative stress and epicardial fat: a pilot study. Nephrol. Dial. Transplant. 2010; 25(8): 2695-2701. https://doi.org/10.1093/ndt/gfq106

9. Mobbs CV, Makimura H. Block the FAS, lose the fat. Nat. Med. 2002; 8: 335-336. https://doi.org/10.1038/nm0402-335

10. Johansen KL, Young B, Kaysen GA, Chertow GM. Association of body size with outcomes among patients beginning dialysis 1-5. Am. J. Clin. Nutr. 2004; 80(2): 324-332. https://doi.org/10.1093/ajcn/80.2.324

11. Carrero JJ, Johansen KL, Lindholm B, Stenvinkel P, Cuppari L, Avesani CM. Screening for muscle wasting and dysfunction in patients with chronic kidney disease. Kidney Int. 2016; 90(1): 53-66. https://doi.org/10.1016/j.kint.2016.02.025

12. Beckham SG, Harper M. Functional training. ACSMs. Health Fit. J. 2010; 14(6): 24-30. https://doi.org/10.1249/FIT.0b013e3181f8b3b7

13. Brill PA. Functional fitness for older adults. Champaign: Human Kinetics; 2004.

14. Liu C, Shiroy DM, Jones LY, Clark DO. Systematic review of functional training on muscle strength, physical functioning, and activities of daily living in older adults. Eur. Rev. Aging Phys. Act. 2014; 11, 95-106. https://doi.org/10.1007/s11556-014-0144-1

15. Bogataj Š, Pajek M, Pajek J, Buturović Ponikvar J, Paravlic A. Exercise-based interventions in hemodialysis patients: a systematic review with a meta-analysis of randomized controlled trials. J. Clin. Med. 2020; 9(1): 43. https://doi.org/10.3390/jcm9010043

16. Bogataj Š, Pajek J, Buturović Ponikvar J, Hadžić V, Pajek M. Kinesiologist-guided functional exercise in addition to intradialytic cycling program in end-stage kidney disease patients: a randomised controlled trial. Sci. Rep. 2020; 10: 5717. https://doi.org/10.1038/s41598-020-62709-1 
17. Negri AL, Barone R, Veron D, Fraga A, Arrizurieta E, Zucchini A, et al. Lean mass estimation by creatinine kinetics and dual-energy x-ray absorptiometry in peritoneal dialysis. Nephron. Clin. Pract. 2003; 95(1): c9c14. https://doi.org/10.1159/000073013

18. Gupta N, Balasekaran G, Govindaswamy V, Hwa CY, Shun LM. Comparison of body composition with bioelectric impedance (BIA) and dual energy X-ray absorptiometry (DEXA) among Singapore Chinese. J. Sci. Med. Sport. 2011; 14(1): 33-35. https://doi.org/10.1016/j.jsams.2010.04.005

19. Di Iorio BR, Scalfi L, Terracciano V, Bellizzi V. A systematic evaluation of bioelectrical impedance measurement after hemodialysis session. Kidney Int. 2004; 65(6): 2435-2440. https://doi.org/10.1111/j.1523-1755.2004.00660.x

20. Kushner RF, Roxe DM. Bipedal bioelectrical impedance analysis reproducibly estimates total body water in hemodialysis patients. Am. J. Kidney Dis. 2002; 39(1): 154-158. https://doi.org/10.1053/ajkd.2002.29907

21. Wang YW, Lin TY, Peng CH, Huang JL, Hung SC. Factors associated with decreased lean tissue index in patients with chronic kidney disease. Nutrients. 2017; 9(5): 434. https://doi.org/10.3390/nu9050434

22. Marcelli D, Usvyat LA, Kotanko P, Bayh I, Canaud B, Etter M, et al. Body composition and survival in dialysis patients: results from an international cohort study. Clin. J. Am. Soc. Nephrol. 2015; 10(7): 1192-1200. https://doi.org/10.2215/CJN.08550814

23. Hickel S. Weight management tips for patients on hemodialysis. J. Ren. Nutr. 2010; 20(5): e21-e22. https://doi.org/10.1053/j.jrn.2009.10.001

24. Herselman M, Esau N, Kruger JM, Labadarios D, Moosa MR. Relationship between Body Mass Index and mortality in adults on maintenance hemodialysis: a systematic review. J. Ren. Nutr. 2010; 20(5): 281-292.e7. https://doi.org/10.1053/j.jrn.2010.03.010

25. Kalantar-Zadeh K, Abbott KC, Salahudeen AK, Kilpatrick RD, Horwich TB. Survival advantages of obesity in dialysis patients. Am. J. Clin. Nutr. 2005; 81(3): 543-554. https://doi.org/10.1093/ajcn/81.3.543

26. Rymarz A, Gibińska J, Zajbt M, Piechota W, Niemczyk S. Low lean tissue mass can be a predictor of one-year survival in hemodialysis patients. Ren. Fail. 2018; 40(1): 231-237. https://doi.org/10.1080/0886022X.2018.1456451

27. Peterson MD, Sen A, Gordon PM. Influence of resistance exercise on lean body mass in aging adults: a metaanalysis. Med. Sci. Sports Exerc. 2011; 43(2): 249-258. https://doi.org/10.1249/MSS.0b013e3181eb6265

28. Port FK, Ashby VB, Dhingra RK, Roys EC, Wolfe RA. Dialysis dose and body mass index are strongly associated with survival in hemodialysis patients. J. Am. Soc. Nephrol. 2002; 13: 1061-1066.

29. Park J, Ahmadi SF, Streja E, Molnar MZ, Flegal KM, Gillen D, et al. Obesity paradox in end-stage kidney disease patients. Prog. Cardiovasc. Dis. 2014; 56(4): 415-425. https://doi.org/10.1016/j.pcad.2013.10.005

30. Ladhani M, Craig JC, Irving M, Clayton PA, Wong G. Obesity and the risk of cardiovascular and all-cause mortality in chronic kidney disease: a systematic review and meta-analysis. Nephrol. Dial. Transplant. 2017; 32(3): 439-449. https://doi.org/10.1093/ndt/gfw075 